\title{
Pengaruh Lama Pemanasan Bakteriosin dari Isolat Bal PR.6.10.5 dan PR.6.15.2 Terhadap Daya Hambat Pertumbuhan Staphylococcus aureus ATCC 25923 dan Escherichia coli ATCC 8739
}

The Effect of Heating Time of Bateriocinfrom LAB Isolates PR.6.10.5 and PR.6.15.2 on theGrowth Inhibition of Staphylococcus aureus ATCC 25923 and Escherichia coli ATCC 8739

\author{
Sarah Yohana Sihombing, Nyoman Semadi Antara ${ }^{*}$, Gusti Ayu Lani Triani \\ PS Teknologi Industri Pertanian, Fakultas Teknologi Pertanian, Universitas Udayana, Kampus Bukit \\ Jimbaran, Badung, Kode pos : 80361; Telp/Fax : (0361) 701801
}

Diterima 23 Agustus 2021 / Disetujui 30 Agustus 2021

\section{ABSTRACT}

After being heated at $100^{\circ}$ Celcius, the bacteriocins from the pickled LAB of tabah bamboo shoots hypothetically predicted to be able to inhibit the growth of pathogenic bacteria, especially $S$. aureus ATCC 25923 and E. coli ATCC 8739. The LAB isolates thus were heated at a temperature of $100 \mathrm{o} C$ for various of 5, 10, 15 minutes heating time and subsequently measured by regression and correlation analysis of its influence towards the inhibition of the growth of $S$. aureus ATCC 25923 and E. coli ATCC 8739 bacterias. This study shows the variations of heating time at a temperature of $100^{\circ} \mathrm{C}$ resulted with of inhibition zone's diameter formation ( $\mathrm{mm})$, activity values $(\mathrm{mm} 2 / \mathrm{ml})$, and the effects (rdan R2) of these two bacteriocins towards its inhibition on the bacterias.

Keywords: Lactic acid bacteria (LAB), bacteriocin, Staphylococcus aureus ATCC 25923, Escherichia coli ATCC 8739, heating time.

\section{ABSTRAK}

Setelah dipanaskan pada suhu $100^{\circ}$ Celcius, bakteriosin dari BAL asinan rebung bambu tabah diasumsikan akan mampu menghambat bakteri patogen khususnya bakteri Staphylococcus aureus ATCC 25923 dan Escherichia coli ATCC 8739. Bakteriosin isolat BAL PR.6.10.5 dan PR.6.15.2 kemudian dipanaskan pada suhu $100^{\circ} \mathrm{C}$ selama $0,5,10$, dan 15 menit dan diukur dengan analisis regresi serta korelasi terhadap variabel penghambatan pertumbuhan bakteri S. aureus ATCC 25923 danEscherichia coli ATCC 8739. Penelitian menunjukkan variasi waktu dalam pemanasan suhu $100^{\circ} \mathrm{C}$ menghasilkan pembentukan diameter zona hambat $(\mathrm{mm})$, nilai aktivitas $\left(\mathrm{mm}^{2} / \mathrm{ml}\right)$, dan pengaruh $\left(\mathrm{r}\right.$ dan $\left.\mathrm{R}^{2}\right)$ kedua bakteriosin terhadap penghambatan bakteri.

Kata kunci: bakteri asam laktat (BAL), bakteriosin, Staphylococcus aureus ATCC 25923, Escherichia coli ATCC 8739, waktu pemanasan.

*Korespondensi Penulis:

Email: semadi.antara@unud.ac.id 


\section{PENDAHULUAN}

Bakteri merupakan makhluk bersel tunggal yang dapat dikategorikan menjadi dua yaitu bakteri yang menguntungkan dan yang merugikan. Bakteri menguntungkan adalah bakteri yang baik bagi tubuh manusia, biasanya juga dibutuhkan dalam bidang pengolahan pangan, industri kecantikan, kesehatan (medis) dan lain sebagainya. Sementara bakteri yang merugikan merupakan bakteri penghasil racun yang kemudian memberikan efek negatif bagi tubuh dan juga lingkungan. Bakteri merugikan sering disebut sebagai bakteri patogen (bakteri perusak) yang dapat diatasi dengan penggunaan antibakteria.

Antibakteria merupakan zat yang dapat menghambat pertumbuhan atau bahkan menginaktifkan bakteri dengan cara menyerang metabolisme bakteri yang merugikan. Salah satu bakteri yang dapat menjadi antibakteri yaitu bakteri asam laktat (BAL). BAL merupakan salah satu bakteri baik yang menguntungkan bagi tubuh, sehingga dapat juga dimanfaatkan dalam proses pengolahan pangan. BAL yang dimanfaatkan dalam proses fermentasi dapat menghasilkan sejumlah antibakteri antara lain: asam organik, hidrogen peroksida $\left(\mathrm{H}_{2} \mathrm{O}_{2}\right)$, dan bakteriosin.Dalam penelitian ini, bakteriosin menarik untuk diteliti lebih lanjut khususnya yang diisolasi dari asinan rebung bambu tabah.

Pada penelitian terkait sebelumnya yang dilakukan oleh Arya Sujana et al., (2020) diketahui bahwa BAL dari asinan rebung bambu tabah menghasilkan bakteriosin sebagai substansi antibakteri penghambat senyawa bakteri lain dengan keistimewaan dapat bertahan pada suhu tinggi. Hasil dari penelitian tersebut mengemukakan bahwa aktivitasbakteriosin dengan kode PR.6.10.5 dan PR.6.15.2 yang dipanaskan pada suhu $80^{\circ} \mathrm{C}, 100^{\circ} \mathrm{C}$ dan $121^{\circ} \mathrm{C}$ serta tanpa pemanasan mampu menghambat pertumbuhan bakteri indikator Lactobacillus plantarum sebesar 567,29 $\mathrm{mm}^{2} / \mathrm{ml}$ sampai $1017,36 \mathrm{~mm}^{2} / \mathrm{ml}$. Suhu pemanasan tersebut merupakan suhu pemanasan yang biasanya digunakan dalam proses pengolahan pangan.

Hasil penelitian tersebut menunjukkan bahwa bakteriosin yang berasal dari asinan rebung bambu tabah memiliki potensi sebagai antibakteri, karena mampu menghambat bakteri indikator Lactobacillus plantarum pada suhu tinggi. Pengujian lebih lanjut menarik untuk dilakukan untuk mengetahui apakah bakteriosin dari isolat BAL asinan rebung bambu tabah mampu menghambat pertumbuhan bakteri patogen lain seperti Staphylococcus aureus ATCC 25923 dan Escherichia coli ATCC 8739. Kedua bakteri pada dasar nya merupakan mikroflora alami yang normal terdapat pada organ tubuh manusia (Kudva et al., 1996). Namun, keduanya akan menjadi cemaran atau kontaminasi jika terdapat dalam produk pangan dan berbahaya jika dikonsumsi oleh manusia (Swarbrick,2004).

Berdasarkan hipotesa sementara, bakteriosin dari isolat BAL PR.6.10.5 dan PR.6.15.2 mampu menghambat pertumbuhan bakteri S. aureus ATCC 25923 dan Escherichia coli ATCC 8739. Selain itu, diasumsikan juga bahwa penelitian lebih lanjut perlu dilakukan melalui pemanasan bakteriosin dari isolat BAL PR.6.10.5 dan PR.6.15.2 pada suhu $100^{\circ} \mathrm{C}$ selama 5, 10, 15 menit dan tidak dipanaskan untuk memperoleh informasi terkait pengaruh waktu pemanasan terhadap kemampuannya menghambat pertumbuhan bakteri $S$. aureus ATCC 25923 dan Escherichia coli ATCC 8739.

Dengan demikian, penelitian akan dilakukan dengan rumusan masalah terkait pembuktian dari kedua hipotesa di atas dengan tujuan untuk mengetahui kemampuan bakteriosin dari isolat BAL PR.6.10.5 dan 
PR.6.15.2 yang dipanaskan pada suhu $100^{\circ} \mathrm{C}$ dan pengaruh waktu pemanasan terhadap kemampuan kedua bakteriosin. Pembahasan permasalahan di atas diharapkan dapat memberi informasi yang berujung pada pemanfaatan bakteriosin tersebut dalam industri pengolahan pangan.

\section{METODE PENELITIAN}

Penelitian ini merupakan penelitian kuantitatif dengan pendekatan berupa eksperimental, yaitu melihat dan pengaruh lama pemanasan bakteriosin isolat BAL pada suhu $100^{\circ} \mathrm{C}$ terhadap daya hambat pertumbuhan bakteri uji yakni bakteri $S$. aureus ATCC 25923 dan Escherichia coli ATCC 8739.

Terdapat 2 faktor yang akan manjadi acuan pada penelitian ini. Faktor pertama adalah faktor lama pemanasan bakteriosin pada suhu $100^{\circ} \mathrm{C}$ dengan level waktu 0 (T1), 5 (T2), 10 (T3) dan 15 (T4) menit.

Faktor yang kedua adalah pengaruh pemanasan bakteriosin terhadap kemampuannya menghambat pertumbuhan bakteri uji patogen. Setiap unit percobaan akan dilakukan pengulangan sebanyak 2 kali, guna memvalidasi data yang diperoleh memiliki hasil yang konstan.

Penelitian ini dilakukan dengan menggunakan alat, bahan dan media yang digunakan sesuai dengan tahapan sebagai berikut:

\section{(1) Pembuatan media MRS Broth untuk perbanyakan BAL dan produksi bakteriosin \\ MRS Broth ditimbang sebanyak 26,1} gram, dimasukkan ke dalam gelas beker, dilarutkan dengan akuades hingga volume $500 \mathrm{ml}$. Larutan didistribusikan ke dalam tabung reaksi dengan tiap-tiap tabung reaksi berisi $5 \mathrm{ml}$, tutup menggunakan kapas. sterilisasi media menggunakanautoklaf pada suhu $121^{\circ} \mathrm{C}$ selama 15 menit.
(2) Pembuatan media Nutrient Agar untuk media penanaman

Media NA ditimbang sebanyak $14 \mathrm{~g}$ dalam $500 \mathrm{ml}$ aquades. Media dipanaskan dan dihomogenkan dengan menggunakanhot stirer hingga mendidih, kemudian disterilisasi dengan autoklaf pada suhu $121^{\circ} \mathrm{C}$ selama 15 menit, sehinggadidapatkan media NA yang steril. Media NA didistribusikan ke dalam cawan petri, masing-masing $\pm 20 \mathrm{ml}$ dan dibiarkan memadat.

\section{(3) Pembuatan media Lactose Broth untuk peremajaan bakteri uji}

Sebanyak 3,25g LB dilarutkan ke dalam $500 \mathrm{ml}$ aquades. Larutan kemudian didistribusikan ke dalam tabung reaksi masing-masing sebanyak $5 \mathrm{ml}$. Media kemudian disterilisasi menggunakan autoklaf pada suhu $121^{\circ} \mathrm{C}$ selama 15 menit.

\section{(4) Perbanyakan isolat BAL}

Perbanyakan bakteri asam laktat dilakukan dengan menginokulasi BAL PR.6.10.5 dan PR.6.15.2 masing - masing sebanyak $100 \mu \mathrm{l}$ ke dalam tabung reaksi yang berisi $5 \mathrm{ml}$ MRS Broth steril, laludiinkubasi kecepatan $120 \mathrm{rpm}$ dan suhu $37^{\circ} \mathrm{C}$ selama 24 jam hingga media menjadi keruh. Tuang kultur aktif yang diperoleh ke dalam tabung reaksi berisi media MRSB $20 \mathrm{ml}$ steril, inkubasi kembali, lalu disentrifugasi dengan kecepatan $8500 \mathrm{rpm}$ suhu $4^{\circ} \mathrm{C}$ selama 25 menit. Supernatan kemudian dibuang dan endapan dipipet sebanyak $250 \mu \mathrm{l}$ yang kemudian diinokulasi ke media MRSB $5 \mathrm{ml}$. Inkubasikembali dengan incubator shaker kecepatan $120 \mathrm{rpm}$ dan suhu $37^{\circ} \mathrm{C}$ selama 24 jam. Kultur aktif BAL PR.6.10.5 dan PR.6.15.2 yang dihasilkan siap digunakan untuk produksi bakteriosin dan pengujian pengaruh lama pemanasan bakteriosin pada suhu $100^{\circ} \mathrm{C}$.

(5) Peremajaan bakteri uji untuk pengujian daya hambat bakteriosin kepada bakteri patogen

Setiap kultur stok $S$. aureus ATCC 
25923 dan E. coli ATCC 8739 dari biakan murninya diambil sebanyak $100 \square \mathrm{L}$, inokulasi pada media LB $5 \mathrm{ml}$, lalu inkubasikan dengan dengan kecepatan 120 rpm dan suhu $37^{\circ} \mathrm{C}$ selama 24 jam hingga media menjadi keruh. Encerkan kultur aktif yang diperoleh dengan penambahan $\mathrm{NaCl} 9 \%$ hingga mencapai hasil pembacaan sama dengan McFarland.

\section{(6) Produksi Baktriosin dan Pemanasan Bakteriosin}

Inkubasi isolat BAL PR.6.10.5 dan PR.6.15.2 selama 24 jam, uji ketahanannya pada suhu $100^{\circ} \mathrm{C}$ dengan variasi lama waktu pemanasan yaitu selama $0,5,10$ dan 15 menit kemudian diamkan hingga mencapai suhu ruang. Distribusikan isolat ke dalam tabung sentifuge yang dilakukan secara aseptis di dalam laminar air flow, lalu dinginkan dengan bantuan es batu yang telah dihaluskan sebelumnya. Isolat kemudian disentrifugasi dengan kecepatan $8500 \mathrm{rpm}$, suhu $4^{\circ} \mathrm{C}$ selama 25 menit. Distribusikan cell free supernatant yang dihasilkan ke dalam tabung reaksi steril,tambahkan $\mathrm{NaOH} 1 \mathrm{~N}$ steril hingga $\mathrm{pH}$ netral mencapai 6,8 dan siap diuji terhadap bakteri patogen.

\section{(7) Uji Daya Hambat Bakteriosin pada Bakteri Uji}

Uji secara in vitro dengan metode difusi agar dengan paperdisk oxoid.Suspensi bakteri S. aureus ATCC 25923 dan E. coli ATCC 8739 dengan pengolesansecara merata sebanyak $20 \mu \mathrm{L}$ pada permukaan medium NA yang telah disterilkan pada cawan petri dan memadat dengan menggunakan batang bengkok.Teteskan $50 \mu \mathrm{L}$ isolat bakteriosin dari BAL PR.6.10.5 dan PR.6.15.2 pada kertas cakram, tempelkan pada permukaan medium NA yang diolesi suspensi bakteri, kemudian diinkubasi pada suhu $37^{\circ} \mathrm{C}$ selama 24. Ukur diameter bakteri dan zona hambat yang timbul di sekitar kertas saring.Gunakan aquades untuk kontrol negatif dan antibiotik kloramphenicol untuk kontrol positif. Aktivitas daya hambat isolat tersebut dapat dilihat dengan terbentuknya zona bening disekitar kertas saring.

Penelitian ini dilakukan di Laboratorium Biondustri dan Ligkungan, Laboratorium Mikrobiologi Pangan, Laboratorium Rekayasa dan Pengedalian Mutu dan Laboratorium Analisis Pangan, Fakultas Teknologi Pertanian, Universitas Udayana. Waktu pelaksanaan dilakukan pada bulan April hingga Juni 2021.

\section{HASIL DAN PEMBAHASAN}

\section{Zona Hambat yang Terbentuk}

Daya hambat bakteriosin isolat BAL asinan rebung bambu tabah kode PR.6.10.5 dan PR.6.15.2 terhadap pertumbuhan bakteri S. aureus ATCC 25923 dan E. coli ATCC 8739 ditunjukkan dengan adanya zona hambat disekitar kertas saring seperti pada Gambar 1.

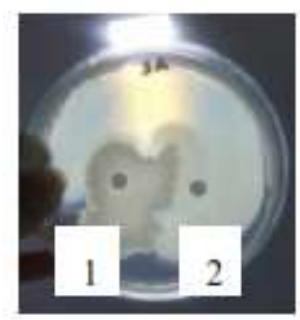

(a)

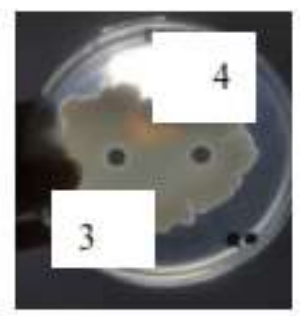

A

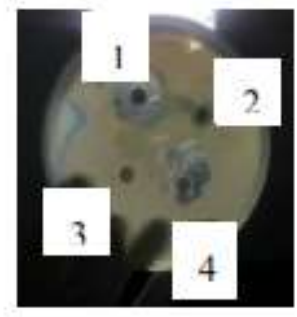

(b)

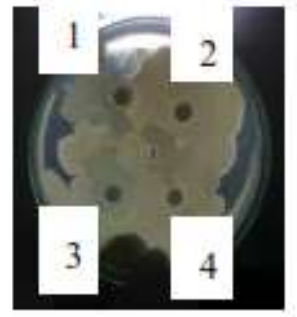

(c)

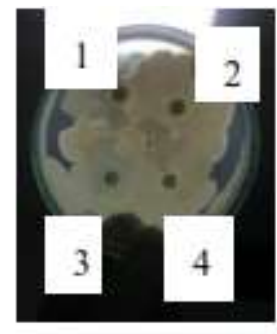

(d)

Gambar 1. A. Hasil uji daya hambat bakteriosin isolat BAL PR.6.10.5(a) dan PR.6.15.2(b) dengan lama pemanasan 0 menit (1), 5 menit (2), 10 menit (3), dan 15 menit (4) terhadap S. aureus ATCC 25923, B. Hasil uji daya hambat bakteriosin isolat BAL PR.6.10.5(c) dan 
PR.6.15.2(d) dengan lama pemanasan 0 menit (1), 5 menit (2), 10 menit (3), dan 15 menit (4) terhadap E. coli ATCC 8739.

Pada Gambar 1, dapat dilihat bahwa bakteriosin yang dihasilkan dari isolat $\mathrm{BAL}$ asinan rebung bambu tabah mampu menghambat pertumbuhan bakteri patogen S. aureus ATCC 25923 dan E. coli ATCC 8739. Dibuktikan dari terbentuknya zona hamba pada media NA yang diinokulasidengan bakteri S. aureus ATCC 25923 dan E. coli ATCC 8739. Suatu isolat BAL dapat dikatakan mampu menghambat pertumbuhan bakteri lain apabila pada saat penguji, zona hambat atau zona bening yang dihasilkan mencapai diameter lebih besar atau sama dengan $1 \mathrm{~mm}$ (Hariani, 2013).

Menurut Susanto et.al., (2012) apabila diameter zona hambat yang dihasilkan sebesar $5 \mathrm{~mm}$ atau kurang dikategorikan lemah, zona hambat 5-10 mm dikategorikansedang, zona hambat $10-20 \mathrm{~mm}$ dikategorikan kuat dan zona hambat $20 \mathrm{~mm}$ atau lebih dikategorikan sangat kuat. Diameter zona hambat yang dihasilkan dari bakteriosin isolat BAL asinan rebung bambu tabah kode PR.6.10.5 dan PR.6.15.2 yang dipanaskan pada suhu $100^{\circ} \mathrm{C}$ selama $0,5,10$ dan 15 menit pada pertumbuhan bakteri patogen S. aureus ATCC 25923 dan E. coli ATCC 8739 dapat dilihat pada Tabel 1.

Zona hambat yang dihasilkan menunjukkan adanya aktivitas antibakteri yang dihasilkan dari isolat BAL PR.6.10.5 dan BAL PR.6.15.2. Pemanasan yang dilakukan pada sampel juga mempengaruhi aktivitas bakteriosin dalam menghambat pertumbuhan bakteri uji $S$. aureus ATCC 25923 dan E. coli ATCC 8739.

\section{Aktivitas Bakteriosin sebagai Antibakteri}

Pada Tabel 1 dapat dilihat zona hambat yang dihasilkan dari pemanasan bakteriosin isolat BAL PR.6.10.5 terhadap pertumbuhanbakteri S. aureus ATCC 25923 pada suhu $100^{\circ} \mathrm{C}$ selama 0 dan 5 menit aktivitas penghambatan dikategorikan dalam intensitas lemah, selama 10 menit dikategorikan dalam intensitas kuat, dan pemanasan selama 15 menit dikategorikan dalam intensitas sedang. Zona hambat dihasilkan pemanasan bakteriosin isolat BAL PR.6.15.2 terhadap pertumbuhan bakteri $S$. aureus ATCC 25923 pada suhu $100^{\circ} \mathrm{C}$ selama 0 menit tidak ditemukan aktivitas penghambatan, pemanasan bakteriosin selama 5 dan 10 menit dikategorikan dalam intensitas sedang dan selama 15 menit dikategorikan dalam intensitas lemah.

Tabel 1. Hasil pengukuran zona hambat bakteriosin isolat BAL PR.6.10.5 dan PR. 6.15.2 terhadap pertumbuhan bakteri patogen $\mathrm{S}$. aureus ATCC 25923 dan E. coli ATCC 8739.

\begin{tabular}{|c|c|c|c|c|}
\hline $\begin{array}{l}\text { Bakteri } \\
\text { UjI }\end{array}$ & $\begin{array}{l}\text { Nama } \\
\text { Sample }\end{array}$ & $\begin{array}{l}\text { Kode } \\
\text { Sample }\end{array}$ & $\begin{array}{l}\text { Lama } \\
\text { pemanasan } \\
\left(100^{\circ} \mathrm{C}\right) / \text { menit }\end{array}$ & \begin{tabular}{|l|} 
Rata-Rata \\
Diameter \\
Zona \\
Hambat \\
(mm) \\
\end{tabular} \\
\hline \multirow{8}{*}{$\begin{array}{l}\text { S. } \\
\text { aureus } \\
\text { ATCC } \\
25923\end{array}$} & \multirow{4}{*}{ PR.6.10.5 } & $\mathrm{I}_{1} \mathrm{~T}_{1} / \mathrm{a}_{1}$ & 0 & 3,67 \\
\hline & & $\mathrm{I}_{1} \mathrm{~T}_{2} / \mathrm{a}_{2}$ & 5 & 5,00 \\
\hline & & $\mathrm{I}_{1} \mathrm{~T}_{3} / \mathrm{aj}$ & 10 & 11,50 \\
\hline & & $\mathrm{T}_{1} \mathrm{~T}_{4 / \mathrm{a}_{4}}$ & 15 & 8,67 \\
\hline & \multirow{4}{*}{ PR.6.15.2 } & $\mathrm{I}_{1} \mathrm{~T}_{1 / a_{1}}$ & 0 & 0,48 \\
\hline & & $\mathrm{l}_{1} \mathrm{~T}_{2} / \mathrm{a}_{2}$ & 5 & 8,17 \\
\hline & & $\mathrm{I}_{1} \mathrm{~T}_{3} / \mathrm{az}_{3}$ & 10 & 9,00 \\
\hline & & $\mathrm{T}_{1} \mathrm{~T}_{4} / \mathrm{a}_{4}$ & 15 & 4,00 \\
\hline \multirow{8}{*}{$\begin{array}{l}\text { E. coli } \\
\text { ATCC } \\
8739\end{array}$} & \multirow{4}{*}{ PR.6.10.5 } & $\mathrm{I}_{1} \mathrm{~T}_{1} / \mathrm{a}_{1}$ & 0 & 3,00 \\
\hline & & $\mathrm{I}_{1} \mathrm{~T}_{2} / \mathrm{a}_{2}$ & 5 & 6,50 \\
\hline & & $\mathrm{I}_{1} \mathrm{~T}_{3} / \mathrm{a}_{3}$ & 10 & 8,17 \\
\hline & & $\mathrm{I}_{1} \mathrm{~T}_{4} / \mathrm{a}_{4}$ & 15 & 4,00 \\
\hline & \multirow{4}{*}{ PR.6.15.2 } & $\mathrm{I}_{1} \mathrm{~T}_{1} / \mathrm{a}_{1}$ & 0 & 9.00 \\
\hline & & $\mathrm{I}_{1} \mathrm{~T}_{2} / \mathrm{a}_{2}$ & 5 & 9,00 \\
\hline & & $\mathrm{I}_{1} \mathrm{~T}_{3} / \mathrm{a}_{3}$ & 10 & 7,00 \\
\hline & & $\mathrm{I}_{1} \mathrm{~T}_{4} / \mathrm{a}_{4}$ & 15 & 0,48 \\
\hline \multicolumn{3}{|c|}{ Kontrol + (Klorafenikol) } & - & 65,00 \\
\hline \multicolumn{3}{|c|}{ Kontrol - (Aquadest) } & - & - \\
\hline
\end{tabular}

Sumber: data diolah (2021)

Zona hambat yang dihasilkan dari pemanasan bakteriosin isolat BALPR.6.10.5 terhadap pertumbuhan bakteri E. coli ATCC 8739 pada suhu $100^{\circ} \mathrm{C}$ selama 0 ATCC 8739 , aktivitas penghambatan pertumbuhan bakteri patogen terbesar ditunjukan oleh bakteriosin isolat BALPR.6.15.2 yang tidak dipanaskan dan yang menit aktivitas penghambatan: intensitas lemah, selama 5\&10 menit: 
intensitas sedang dan pemanasan bakteriosin selama 15 menit: intensitas lemah. Pada pemanasanbakteriosin isolat BAL PR.6.15.2 suhu $100^{\circ} \mathrm{C}$ terhadap pertumbuhan bakteri $E$. coliATCC 8739 pada suhu $100^{\circ} \mathrm{C}$ selama 0,5
\&10 menit: aktivitas penghambatan dengan intensitas sedang. Pemanasan bakteriosin selama 15 menit tidak ditemukan adanya penghambatan.

Tabel 2. Nilai aktivitas bakteriosin (AU) isolat BAL PR.6.10.5 dan PR. 6.15.2 terhadap dayahambat pertumbuhan bakteri patogen $S$. aureus ATCC 25923 dan E. coli ATCC 8739

\begin{tabular}{|c|c|c|c|c|c|c|c|c|}
\hline Bakteri Uji & $\begin{array}{c}\text { Nama } \\
\text { Sample }\end{array}$ & $\begin{array}{c}\text { Kode } \\
\text { Sample }\end{array}$ & $\begin{array}{c}\text { Lama } \\
\text { pemanasan } \\
\left(100^{\circ} \mathrm{C}\right) / \text { menit }^{2}\end{array}$ & $\begin{array}{c}\text { Rata- Rata } \\
\text { Diameter } \\
\text { Zona } \\
\text { Bening } \\
(\mathrm{mm})\end{array}$ & $\begin{array}{c}\text { Luas Zona } \\
\operatorname{Bening}(\mathbf{L z}) \\
\quad(\mathrm{mm} 2)\end{array}$ & $\begin{array}{c}\text { Luas } \\
\text { Kertas } \\
\text { Cakram } \\
(\mathbf{m m 2})\end{array}$ & $\begin{array}{c}\text { Volume } \\
\text { Sample } \\
(\mathrm{ml})\end{array}$ & $\begin{array}{c}\text { Nilai } \\
\text { Aktivitas } \\
\text { bakteriosin } \\
\text { (AU) } \\
\text { (mm2/ml) }\end{array}$ \\
\hline & & I1T1/a1 & 0 & 3,67 & 2,88 & 0,47 & 0,05 & 48,15 \\
\hline \multirow{7}{*}{$\begin{array}{l}\text { S. aureus } \\
\text { ATCC } \\
25923\end{array}$} & \multirow[t]{3}{*}{ PR.6.10.5 } & I1T2/a2 & 5 & 5,00 & 3,93 & 0,47 & 0,05 & 69,08 \\
\hline & & I1T3/a3 & 10 & 11,50 & 9,03 & 0,47 & 0,05 & 171,13 \\
\hline & & I1T4/a4 & 15 & 8,67 & 6,80 & 0,47 & 0,05 & 126,65 \\
\hline & \multirow{4}{*}{ PR.6.15.2 } & I1T1/a1 & 0 & 0,00 & 0,00 & 0,47 & 0,05 & 0,18 \\
\hline & & I1T2/a2 & 5 & 8,17 & 6,41 & 0,47 & 0,05 & 118,85 \\
\hline & & I1T3/a3 & 10 & 9,00 & 7,07 & 0,47 & 0,05 & 131,88 \\
\hline & & I1T4/a4 & 15 & 4,00 & 3,14 & 0,47 & 0,05 & 53,38 \\
\hline & & I1T1/a1 & 0 & 3,00 & 2,36 & 0,47 & 0,05 & 37,68 \\
\hline \multirow{7}{*}{$\begin{array}{l}\text { E. coli } \\
\text { ATCC8739 }\end{array}$} & \multirow[t]{3}{*}{ PR.6.10.5 } & I1T2/a2 & 5 & 6,50 & 5,10 & 0,47 & 0,05 & 92,63 \\
\hline & & I1T3/a3 & 10 & 8,17 & 6,41 & 0,47 & 0,05 & 118,85 \\
\hline & & I1T4/a4 & 15 & 4,00 & 3,14 & 0,47 & 0,05 & 53,38 \\
\hline & \multirow{4}{*}{ PR.6.15.2 } & I1T1/a1 & 0 & 9,00 & 7,07 & 0,47 & 0,05 & 131,88 \\
\hline & & I1T2/a2 & 5 & 9,00 & 7,07 & 0,47 & 0,05 & 131,88 \\
\hline & & I1T3/a3 & 10 & 7,00 & 5,50 & 0,47 & 0,05 & 100,48 \\
\hline & & I1T4/a4 & 15 & 0,00 & 0,00 & 0,47 & 0,05 & 0,18 \\
\hline
\end{tabular}

Sumber: data diolah (2021)

Zona hambat terbesar yang mampu menghambat pertumbuhan bakteri patogen S.aureus ATCC 25923 ditunjukan oleh bakteriosin isolat BAL PR.6.10.5 yang dipanaskan di suhu $100^{\circ} \mathrm{C}$ selama 10 menit yakni sebesar 11,50 mm. Pada uji daya hambat pertumbuhan bakteri patogen E. Coli dipanaskan selama 5 menit berdiameter 9,00 $\mathrm{mm}$.

\section{Perhitungan Aktivitas Hambat Bakteriosin}

Diameter zona hambat yang terbentuk menujukkan adanya aktivitas penghambatan yang dilakukan bakteriosin terhadap pertumbuhan bakteri S. aureus ATCC 25923 dan E. coli ATCC 8739. Nilai aktivitas bakteriosin isolat BAL PR.6.10.5 dan
PR.6.15.2 dalam menghambat pertumbuhan bakteri patogen dapat dilihat pada Tabel 2 . Pada Tabel 2, nilai aktivitas bakteriosin isolat BAL PR.6.10.5 yang diujikan pada bakteri uji S. aureus ATCC 25923 yang tidak dipanaskan menunjukan nilai aktivitas bakteriosin sebesar $48,15 \mathrm{~mm}^{2} / \mathrm{ml} \mathrm{kemudian}$ dipanaskan pada suhu $100^{\circ} \mathrm{C}$ selama 5 menit mengalami kenaikan nilai aktivitas bakteriosin (AU) sebesar 20.93\% menjadi $69,08 \mathrm{~mm}^{2} / \mathrm{ml}$, kemudian mengalami kenaikan kembali pada pemanasan suhu $100^{\circ} \mathrm{C}$ selama 10 menit sebesar $102,05 \%$ menjadi $171,13 \mathrm{~mm}^{2} / \mathrm{ml}$. Pada pemanasan dengan lama waktu 15 menit, nilai aktivitas bakteriosin mengalami penurunan sebesar $44.48 \%$ menjadi $126,65 \mathrm{~mm}^{2} / \mathrm{ml}$. 
Nilai aktivitas bakteriosin isolat BAL PR.6.15.2 yang diujikan pada bakteri uji $S$. aureus ATCC 25923 yang tidak dipanaskan menunjukan nilai aktivitas bakteriosin sebesar $0,18 \mathrm{~mm}^{2} / \mathrm{ml}$ kemudian dipanaskan pada suhu $100^{\circ} \mathrm{C}$ selama 5 menit mengalami kenaikan nilai aktivitas bakteriosin (AU) sebesar $118,67 \%$ menjadi $118,65 \mathrm{~mm}^{2} / \mathrm{ml}$, kemudian mengalamikenaikan kembali pada pemanasan suhu $100^{\circ} \mathrm{C}$ selama 10 menit sebesar $13,21 \%$ menjadi $131,88 \mathrm{~mm}^{2} / \mathrm{ml}$. Pada pemanasan dengan lama waktu 15 menit, nilai aktivitas bakteriosin mengalami penurunan sebesar $78,50 \%$ menjadi 53,38 $\mathrm{mm}^{2} / \mathrm{ml}$. Suwayvia (2017) juga melaporkan bahwa bakteriosin yang dihasilkan $L$. plantarum FNCC 0020 memiliki sifat stabil terhadap pemanasan hingga suhu $121^{\circ} \mathrm{C}$ selama 15 menit. Sedangkan Villani et al. (2001) melaporkan bahwa aktivitas antimikroba Lactococcus garvieae L-1 benar-benar hilang setelah pemanasan pada suhu $121^{\circ} \mathrm{C}$ selama 15 menit.

Pada pengujian bakteriosin isolat BAL PR.6.10.5 yang diujikan pada bakteri uji E. coli ATCC 8739 yang tidak dipanaskan menunjukkan nilai aktivitas bakteriosin sebesar $37.68 \mathrm{~mm}^{2} / \mathrm{ml}$. Bakteriosin kemudian dipanaskan pada suhu $100^{\circ}$ Cselama 5 menit mengalami kenaikan nilai aktivitas bakteriosin sebesar 54,95\% menjadi 92,63 $\mathrm{mm}^{2} / \mathrm{ml}$, kemudian pada pemanasan selama 10 menit nilai aktivitas bakteriosin kembali mengalami kenaikan sebesar $26,22 \%$ menjadi $118,85 \mathrm{~mm}^{2} / \mathrm{ml}$. Pemanasan bakteriosin selama 15 menit menunjukan penurunan nilai aktivitas bakteriosin sebesar $65.47 \%$ menjadi $53.38 \mathrm{~mm}^{2} / \mathrm{ml}$.

Pada pengujian bakteriosin isolat BAL PR.6.15.2 yang diuji pada bakteri uji $E$. coli ATCC 8739 yang tidak dipanaskan menunjukkan nilai aktivitas bakteriosin sebesar $131.88 \mathrm{~mm}^{2} / \mathrm{ml}$, kemudian bakteriosin dipanaskan pada suhu $100^{\circ} \mathrm{C}$ selama 5 menit dan tidak menunjukan adanya perubahan nilai aktivitas bakteriosin karena tetap menunjukkan nilai AU sebesar

$131.88 \mathrm{~mm}^{2} / \mathrm{ml}$, pemanasan selama 10 menit nilai aktivitas bakteriosin mengalami penurunan sebesar $31,40 \%$ menjadi $100,48 \mathrm{~mm}^{2} / \mathrm{ml}$ dan kembali mengalami penurunan pada pemanasan selama 15 menit sebesar $100,30 \%$ menjadi $0,18 \mathrm{~mm}^{2} / \mathrm{ml}$.

Sel kebanyakan bakteri akan mengalami kematian jika dipanaskan selama 5-10 menit pada suhu $60-70^{\circ} \mathrm{C}$ dengan panas lembab. Kebanyakan spora bakteri hanya akan terbunuh pada suhu yang dipertahankan diatas $100^{\circ} \mathrm{C}$ selama jangka waktu yang lama (Pelczar, 2012). Panas dapat mengganggu ikatan protein dalam bakeri, namun tidak merubah ikatan kovalennya. Hal ini karena dengan meningkatnya suhu akan membuat energi kinetik molekul bertambah. Bertambahnya energi kinetik akan mengacaukan ikatan-ikatan hidrogen.

Kenaikan suhu yang dialami, akan membuat perubahan entalpi sistem naik. Selain itu bentuk protein yang terdenaturasi dan tidak teratur juga menjadi bukti bahwa entropi akan bertambah. Pemanasan juga dapat mengakibatkan kemampuan protein untuk mengikat air mengalami penurunan dan dapat menyebabkan koagulasi protein (Kumalasari et al., 2012).

Hasil penelitian ini menujukan bahwa bakteriosin yang dipanaskan lebih lama menunjukkan nilai aktivitas bakteriosin yang lebih tinggi dalam menghambat pertumbuhan bakteri uji dibandingkan dengan bakteriosin yang tidak dipanaskan. Pemanasan pada suhu $100^{\circ} \mathrm{C}$ selama 5-10 menit menunjukkan ratarata nilai aktivitas bakteriosin lebih tinggi dibandingkan dengan yang tidak dipanaskan atau yang dipanaskan selama 15 menit. Winarwi (2006) menyatakan suhu yang diberikan dapat mempengaruhi mikroorganisme dalam dua cara yang berlawanan yaitu: 1) Apabila suhu naik, kecepatan mikroorganisme naik dan pertumbuhan dipercepat. Sebaliknya, apabila 
suhu turun, kecepatan metabolisme juga turun dan pertumbuhan diperlambat. 2) Apabila suhu naik atau turun, tingkat pertumbuhan mungkin terhenti, kompenen sel menjadi tidak aktif dan sel-sel dapat mati. Sel bakteri kebanyakan akan dimatikan dalam waktu 5-10 menit pada suhu 60-70oC dengan panas lembab (Pelczar, 2012).

Hal tersebut kemungkinan menjadi penyebab utama bakteriosin yang dipanaskan pada suhu 100oC selama 5-15 menit justru memberikan efek penghambatan yang lebih tinggi terhadap bakteri S. aureus ATCC 25923 dan E. coli ATCC 8739 dibandingkan dengan bakteriosin yang tidak dipanaskan.

Kusmarwati (2014) menjelaskan bahwa masih adanya aktivitas antibakteri oleh bakteriosin ketika terjadinya perlakuan pemanasan diduga karena bakteriosin merupakan peptida pendek yang stabil terhadap panas. Perubahan suhu dan lama pemanasan dapat mengurangi aktivitas biokimia protein (Poedjiadi, 2006). Selain itu, karena adanya asam-asam amino tertentu pada bakteriosin tersebut yang mampu mempertahankan struktur bakteriosin dari pengaruh panas. Najim (2012) menyebutkan bahwa stabilitas terhadap panas dapat dihubungkan dengan formasi struktur globular yang kecil dan menyebabkan kuatnya daerah hidrofobik, kestabilan ikatan silang dan kandungan sistein yang tinggi. Kestabilan terhadap pemanasan ini merupakan suatu keuntungan dan merupakan parameter yang sangat penting jika bakteriosin akan diaplikasikan sebagai pengawet makanan sebab prosedur-prosedur pemrosesan makanan banyak melibatkan pemanasan (Vuyst, 1994;Suwayvia, 2017). Dundar (2006) menyatakan bahwa resistensi terhadap panas merupakan karakteristik umum untuk berbagai jenis bakteriosin yang diproduksi oleh BAL.

\section{Pengaruh Lama Pemanasan Bakteriosin dengan Nilai Aktivitas Bakteriosin}

Hasil penelitian laboratorium menunjukkan bahwa penghambatan yang dilakukan oleh bakteriosin isolat BAL PR.6.10.5 dan PR.6.15.2 yang dipanaskan pada suhu $100^{\circ} \mathrm{C}$ dengan lama pemanasan 5 , 10 dan 15 menit serta tidak dipanaskan baik terhadap bakteri S. aureus ATCC 25923 maupun E. coli ATCC 8739 menunjukkan hasil yang berbeda-beda. Hasil dari perhitungan regresi dan korelasi antara lama pemanasan ( $\mathrm{x}$ ) dengan nilai akivitas bakteriosin (y) diperoleh hasil seperti pada Gambar 3.

Pada Gambar 3(a) menunjukkan pengaruh lama pemanasan bakteriosin dari isolat BAL PR.6.10.5 terhadap nilai aktivitas bakteriosin dalam menghambat bakteri $\mathrm{S}$. aureus ATCC 25923 menghasilkan nilai koefisien korelasi (r) sebesar 0,7803 dapat diartikan bahwa pengaruh lama pemanasan bakteriosin dengan nilai aktivitas bakteriosin dalam menghambat pertumbuhan bakteri S. aureus ATCC 25923 memiliki pengaruh yang kuat.

Nilai koefisien determinasi $\mathrm{R}^{2}$ ) yang diperoleh sebesar 0,6088 yang berarti $60,88 \%$ nilai aktivitas bakteriosin diperoleh karena adanya variasi perlakuan pemanasan, sedangkan 39,12\% lainnya berasal dari faktor luar.

Pada Gambar 3(b) menunjukkan pengaruh lama pemanasan bakteriosin dari isolat BAL PR.6.15.2 terhadap nilai aktivitas bakteriosin untuk menghambat bakteri $S$. aureus ATCC 25923 menghasilkan nilai $\mathrm{r}$ sebesar 0,3644 yang berarti pengaruh lama pemanasan bakteriosin isolat PR.6.15.2 dalam menghambat pertumbuhan bakteri $S$. aureus ATCC 25923 memiliki pengaruh yang lemah. Nilai $\mathrm{R}^{2}$ yang diperoleh sebesar 0,1328 yang berarti $13,28 \%$, nilai akivitas bakteriosin diperoleh karena adanya variasi waktu pemanasan, sedangkan $86,72 \%$ lainnya berasal dari faktor luar lama pemanasan. Beberapa hal yang mempengaruhi besar kecilnya zona hambat yang dibentuk oleh isolat BAL terhadap 
bakteri uji antara lain interaksi antara kemampuan bakteri asam laktat dalam menghasilkan senyawa aktif atau enzim

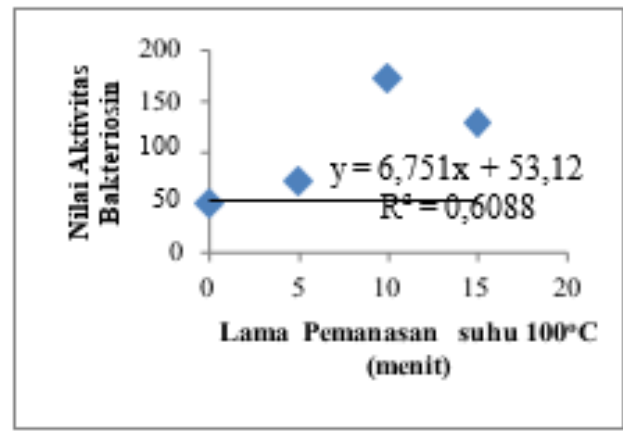

(a)

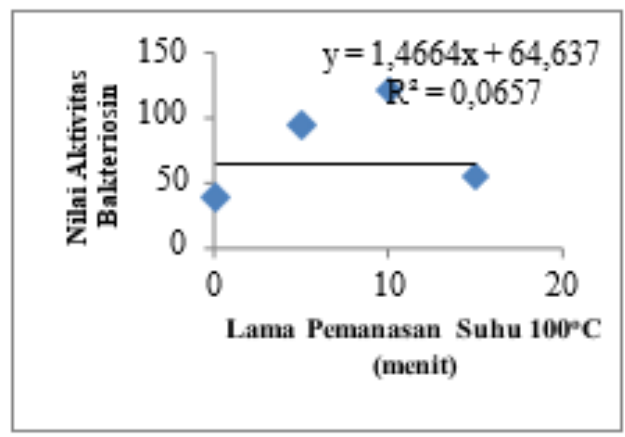

(c) hidrolitik, umur biakan bakteri, jumlah senyawa aktif yang dihasilkan, komposisi medium dan waktu inkubasi (Dewi, 2011).

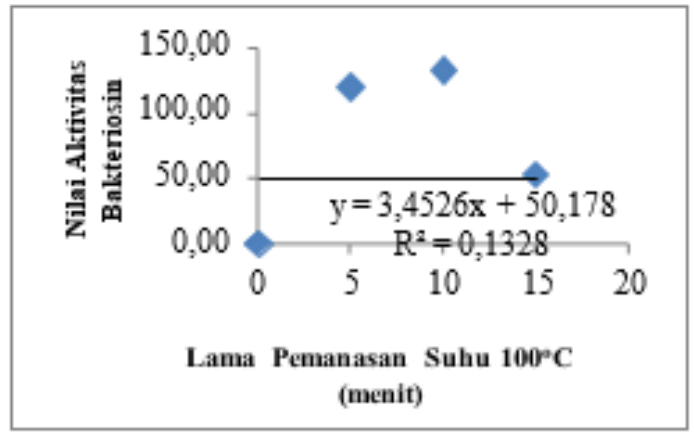

(b)

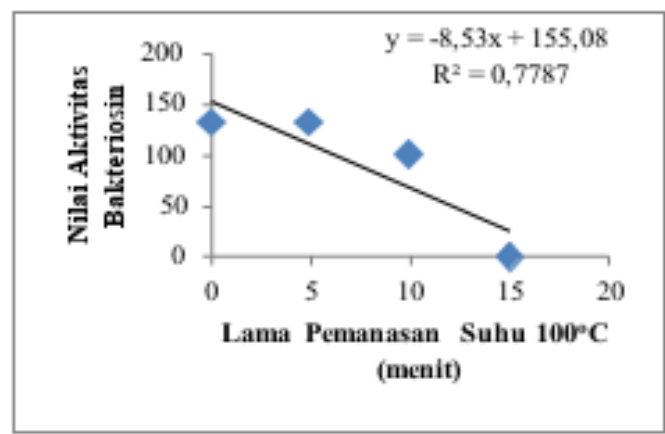

(d)

Gambar 3. (a) Grafik regresi dan korelasi antara lama pemanasan bakteriosin isolat BAL PR.6.10.5 terhadap nilai AU pertumbuhan S. aureus, (b) Grafik regresi dan korelasi antara lama pemanasan bakteriosin isolat BAL PR.6.15.2 terhadap nilai AU pertumbuhan S. aureus b, (c) Grafik regresi dan korelasi antara lama pemanasan bakteriosin isolat BAL PR.6.10.5 terhadap nilai AU pertumbuhan E. coli, (d) Grafik regresi dan korelasi antara lama pemanasan bakteriosin isolat BAL PR.6.15.2 terhadap nilai AU pertumbuhan E. coli.

Pada Gambar 3(c) menunjukkan pengaruh lama pemanasan bakteriosinisolat BAL PR.6.10.5 terhadap nilai aktivitas bakteriosin yang dihasilkan dalam menghambat bakteri E.coli ATCC 8739 menghasilkan nilai $\mathrm{r}$ sebesar 0,2563 yang artinya pengaruh lama pemanasan bakteriosin isolat BAL PR.6.10.5 terhadap bakteri E. coli ATCC 8739 memiliki pengaruh yang lemah. Nilai $\mathrm{R}^{2}$ sebesar 0,0657 yang berarti $6,57 \%$ nilai akivitas bakteriosin diperoleh karena adanya variasi waktu pemanasan, sedangkan 93,43\% lainnya berasal dari faktor diluar lama pemanasan.
Pada Gambar 3(d) menunjukkan pengaruh lama pemanasan bakteriosindari isolat BAL PR.6.15.2 terhadap nilai aktivitas bakteriosin dalam menghambat bakteri $E$. coli ATCC 8739 menghasilkan nilai koefisien korelasi (r) sebesar 0,8824 dapat diartikan bahwa pengaruh lama pemanasan bakteriosin dengan nilai aktivitas bakteriosin dalam menghambat pertumbuhan bakteri $E$. coli ATCC 8739 memiliki pengaruh yang kuat. Nilai $\mathrm{R}^{2}$ yangdiperoleh sebesar 0,7783 yang berarti $77,83 \%$ nilai aktivitas bakteriosin dalam menghambat pertumbuhan bakteri E. coliATCC 8739 diperoleh karena adanya variasi perlakuan pemanasan, 
sedangkan 22,17\% lainnya berasal dari faktor lain di luar lama pemanasan.

\section{KESIMPULAN DAN SARAN}

\section{Kesimpulan}

Berdasarkan penelitian yang telah dilakukan maka dapat disimpulkan beberapahal sebagai berikut:

1. Hasil peneltian pada bakteriosin dari isolat BAL PR.6.10.5 dan PR.6.15.2 dari asinan rebung bambu tabah ini menunjukkanbahwa bakteriosin tersebut yang dipanaskan pada suhu $100^{\circ} \mathrm{C}$ mampu menghambat pertumbuhan bakteri S. aureus ATCC 25923dan E. coli ATCC 8739 ini dibuktikan dengan adanya zona hambat (zona bening) yang terbentuk dalam pengujian. Rata- rata diameter zona hambat bakteriosin dari isolat BAL PR.6.10.5 dan PR.6.15.2 terhadapbakteri S. aureus ATCC 25923 yang terbentuk adalah 3,67-11,50 mm dan terhadap bakteri E. coli ATCC 8739 sebesar 3,00-9,00 mm.

2. Hasil analisis dilaboratorium menunjukkan bahwa lama pemanasan bakteriosin isolat BAL PR.6.10.5 yang dipanaskan dengan suhu $100^{\circ} \mathrm{C}$ selama 5 , 10, 15 menit, dan tanpa pemanasan berpengaruh kuat dalam menghambat pertumbuhan bakteri $S$. aureus ATCC 25923 dengan nilai rsebesar 0,7803 dan $\mathrm{R}^{2}$ sebesar $60,88 \%$.

3. Lama pemanasan bakteriosin BAL PR.6.15.2 yang dipanaskan dengan suhu $100^{\circ} \mathrm{C}$ selama $5,10,15$ menit, dan tanpa pemanasan berpengaruh dalam menghambat pertumbuhan bakteri E. coli ATCC 8739 dengan nilai r sebesar 0,8824 dan nilai $\mathrm{R}^{2}$ sebesar $77,83 \%$. Ini menunjukkan bahwa lama pemanasan bakteriosin terhadap kemampuannya dalam menghambat bakteri E. coli ATCC 8739 memiliki pengaruh yang cukup. Dengan demikian maka disarankanuntuk dilakukan uji pengaplikasian bakteriosin tersebut sebagai bahan pengawet makanan, khususnya pada makanan yang cukup rentan terkontaminasi dengan bakteri S. aureus dan E. Coli dan pengolahannyamenggunakan pemanasan dengan suhu mencapai $100^{\circ} \mathrm{C}$ selama 515 menit.

\section{DAFTAR PUSTAKA}

Dewi F.K. 2010. Aktivitas Antibakteri Ekstrak etanol Buah Mengkudu (Morinda citrifolia, Linnaeus) terhadap Bakteri Pembusuk Daging Segar. Skripsi. Universitas Sebelas Maret, Surakarta.

Dundar, H. 2006. Characterization and Purification of A Bacteriocin Produced by Leuconostoc mesenteroides sub sp. Cremoris. Thesis. Middle East Technical University, Ankara.

Hariani, L. 2013. Produksi Bakteriosin oleh Lacobacillus plantarum Dj3 dan Aplikasinya Sebagai Pengawet Daging. Alchemy: Vol 4(1): 44-45.

Kleerebezem, M and Hugenholtz, J. 2003. Metabolic pathway engineering in lactic acid bacteria. Current Opinion in Biotechnology. 14(2): 232-237.

Kudva, T., Indira, G., Patrick, H and Hovde,

C. J. 1996. Escherichia coli O157: H7 in microbial flora of sheep, Journal of Clinical Microbiology. 34(2): 43-433

Kusmarwati, F., Arifah, R., Arief dan S. Haryati. 2014. Eksplorasi bakteriosin dari bakteri asam laktat asal rusip Bangka dan Kalimantan. JPB Perikanan. 9(1): 29-40.

Najim, Hadi, Z. A., Mohammed and Khudir, Z.S. 2012. The Antibacterial Activity of Bacteriocin Produced by Lactobacillus acidophilus Isolates 
Againts Sensitive Reference Strain Lactobacillus acidophilus R0052 and its Stability to Different $\mathrm{pH}$, Heating and Storage Temperatures. Proceeding of The Eleventh Veterinary Scientific Conference, University of Baghdad. p 274-279.

Pelczar, M. J dan Chan, E. C. S. 2007. Dasardasar mikrobiologi 1. UI Press, Jakarta.

Pelczar, M. J dan Chan, E. C. S. 2012. Dasardasar mikrobiologi 2. UI Press, Jakarta.

Poedjiadi, A. dan Suprayanti, T. 2006. Dasardasar Biokimia. UI Press, Jakarta.

Prescott, L. M., Harley, J. P and Klein, D. A. 2002. Microbiology. McGraw-Hill, USA. Santiyasa, I. W. 2016. Analisis Regresi dan Korelasi. Modul Kuliah. Jurusan Ilmu Komputer. Fakultas Matematika dan Ilmu Pengetahuan Alam. Universitas Udayana, Bali.

Sudjana. 2005. Metode Statistika. Tarsito, Bandung.

Sujana, I.G.A. 2020. Skrining Isolat Bakteri Asam Laktat Penghasil Bakteriosin yang Diisolasi dari Asinan Rebung Bambu Tabah dan Ketahanannya Terhadap Panas. Skripsi. Program Studi Teknologi Industri Pertanian. Fakultas Teknologi Pertanian. Universitas Udayana, Bali.

Suryani, M. S. 2020. Virgin Coconut Oil. Bakteri Asam Laktat dan Bakteriosin. Unitomo Press. Universitas Dr. Soetomo, Surabaya.

Susanto, Sudrajat, D dan Ruga, R. 2012. Studi kandungan bahan aktif tumbuhan meranti merah (Shorea leprosula Miq) sebagai sumber senyawa antibakteri. Mulawarmnan Scientific. 11(2):18190.

Suwayvia, N. 2017. Produksi Bakteriosin Asal Lactobacillus plantarum FNCC
0020 Sebagai Antimikroba dan Stabilitasnya pada Variasi Suhu Pemanasan, Suhu Penyimpanan dan pH. Tesis. Fakultas Sains dan Teknologi Universitas Islam Negeri Maulana Malik Ibrahim Malang, Malang.

Swarbrick, J. 2004. MicrobialContamination Control in the Pharmaceutical Industry.Volume 142. Marcel Dekker Inc., New York.Usmiati, S., Tri, M. 2007. Seleksi dan Optimasi Produksi Bakteriosin dari Lactibacillus sp. Jurnal Penelitian Pascapanen Pertanian. Balai Besar Penelitian dan Pengembangan Pascapanen Pertanian, Bogor.

Vesterlund, S. and Ouwehand, A.C. 2004. Antimicrobial Components From Lactic Acid Bacteria. In Lactic Acid Bacteria: Microbiological and Functional Aspects. New York. pp.375-395.

Vuyst, L. D and E.J. Vandamme. 1994. Antimicrobial Potential of Lactic Acid Bacteria. In Bacteriocins of Lactic Acid Bacteria: Microbiology, Genetic and Application. L.D. Vuystdan E.J. Vandamme (eds.). Blackie Academic \& Professional, London. p91-142.

Winarwi. 2006. Uji Viabilitas Bakteri dan Aktivitas Enzim Bakteri Proteolitik pada Media Carrier Bekantul. Skripsi. Universitas Sebelas Maret, Surakarta. 